\title{
Specifics of the legal regulation of environmental management in agriculture
}

\author{
Anna Kulikova ${ }^{1, *}$ \\ ${ }^{1}$ Institute of Service and Entrepreneurship (Branch) of the Don State Technical University in \\ Shakhty, 147, Shevchenko str., Shakhty town, Rostov region, 346500, Russia
}

\begin{abstract}
It is difficult to overestimate the importance of agriculture, its effectiveness for the economic and socio-political sector of development of any state in the modern world. However, agriculture relies on the use of natural resources in its activities - land, soil, water, atmospheric air, forests and other vegetation. The quality of these natural components of the natural environment directly affects the functioning and productivity of agricultural organizations. Environmental pollution problems are complex problems of interaction between nature and man. To minimize environmental harm and the occurrence of dangerous environmental consequences, a model of environmental management is needed. For agricultural production environmental management issues are particularly specific since its productivity is directly related, first of all, to the state of the natural environment as consumption resources on the one hand, and the negative impact of agricultural activities on natural resources on the other. In this article the issues of legal regulation of the law of nature use in agricultural activities were investigated, the problems of regulatory support for the rational use of nature in agriculture were identified, and the directions for optimizing the legislative regulation of the use of natural resources for agricultural activities were determined.
\end{abstract}

\section{Introduction}

Environmental management issues are the subject of research by Russian and foreign scientists. Environmental issues and environmental protection are the problems of the entire world community. Improving the efficiency of the use of natural resources plays a central role in the development of the economy. For the agro-industrial sector the problem of natural resource use is important, due to such trends as dietary changes towards an increase in the proportion of animal proteins and population growth which indicates an increasing demand for agricultural goods over the next three decades [1,2]. Expanding global agricultural areas or intensifying production through much greater use of inputs is not appropriate to counterbalance this increase as the agricultural sector is already making a significant contribution to exceeding planetary boundaries for biodiversity loss and nitrogen and phosphorus biogeochemical fluxes [3]. However, improving resource efficiency in

\footnotetext{
* Corresponding author: naukatgp@yandex.ru
} 
agriculture can create a favourable situation by improving economic performance and reducing environmental pressures [4,5].

Environmental management in agriculture is the primary matter not only of agricultural organizations and entities engaged in entrepreneurial activities in the agro-industrial complex but of mankind as a whole [6], therefore, it is necessary, first of all, to develop a regulatory framework of international and national law capable of ensuring the fulfillment of this task. In Russia environmental law is a young, developing branch of law. Taking into account climate change [7], factors of human influence on the environment, environmental law must meet the requirements of mobility, timeliness and rationality which requires constant scientific understanding of legal regulation in the field of ensuring the rational use of nature and protection of the natural environment.

\section{Methodology}

The methodological basis of the study is general scientific methods such as dialectical, formal logic, analysis and synthesis; private scientific methods - logical-legal, comparative-legal, system-structural, document analysis, analysis of print and electronic publications, statistical methods.

\section{Results of the research}

The right to use nature in the field of agriculture has its own specifics and characteristics. Unlike other types of environmental management in agriculture, natural resources are a means of consumption and a necessary resource base. Therefore, the state-legal regulation of the use of natural resources in agriculture is of great importance.

Considering the specifics of the right to environmental management in agriculture we make the conclusion that there are no statutory definitions of fundamental concepts. Thus, the term "environmental management" is not disclosed at the legislative level which leads to a different interpretation of this concept and the complexity of determining rational and other types of environmental management. The legislator establishes responsibility for guilty acts that harm the natural environment and its components but in order to improve the situation on the way to environmental management it is not enough not to commit offenses and crimes, but to use natural resources rationally, effectively, carry out measures to fill them and restore them. It is therefore important to establish at the legislative level a concept of environmental management that meets the requirements of the rule of law and incorporates provisions that promote the conservation and protection of resources used for agricultural production.

Considering that agricultural activities are carried out in isolation using one natural resource (for example, land), and comprehensively affect the entire ecosystem in a certain territory, we consider it necessary to consider environmental management comprehensively as part of a special natural-climatic territory created by man in whole or in part, which includes several natural components. In this regard, we support the opinion of Selivanova K.A. on the consolidation of the concept of an agrarian ecosystem as an object of legal protection.

The list of rights and obligations of the environmental user in agriculture in general form is presented in the Land Code, the Law "On Environmental Protection". More detailed rights and obligations are in the special legislation on the use of certain natural resources. The specificity of the legal status of the entity carrying out agricultural activities is the assignment to it of the obligation to carry out measures to preserve and restore the natural environment, rational use of natural resources, ensure environmental safety, prevent negative impact on the environment, as well as carry out standardization in the field of environmental protection. 
I would like to note that in Russian legislation there is a negative factor of the lack of responsibility for the irrational use of natural resources. The first step towards harmonizing the tasks of ecology and agriculture is to clarify the legislative definition of "rational environmental management" which will prevent activities for the non-rational use of natural resources before environmental harm occurs the liability for which is provided for by administrative and criminal legislation.

Organizational, social and economic measures may have a positive impact on the establishment of a course aimed at environmental management in agriculture in addition to legal measures.

\section{Discussion of results}

The term "environmental management" is widely used in Russian legislation but its official interpretation is not enshrined. Thus, this term is contained in the basic law of the State in the Constitution of the Russian Federation, which refers to environmental management as the subject of joint jurisdiction of the subjects and the Russian Federation (para. d, part 1 of the Article 72), the Water Code of the Russian Federation and other federal legislation, by-laws of various levels. Based on the analysis of the studied literature and normative legal acts, environmental management can be determined in three vvalue bearing various meaning loads. Thus, in general terms, environmental management is a set of legal and regulatory requirements that establish the procedure for the use of natural resources to meet various material needs in the economic and other interests of society. The concept also covers the set of rights and obligations of a certain entity implementing its activities through the use of natural resources. Considering environmental management as a legal relationship it can be defined as a mechanism for the implementation of rights and obligations determined by law and other regulatory legal acts.

It is necessary to stabilize the situation with the destructive impact of the activities of agro-industrial production on the environment by establishing at the legislative level regulatory regulations aimed at rational environmental management, as well as to determine the "legality" of environmental management in order to develop agricultural territories. National legislation is provided for legal liability for environmental offences. The Environmental Protection Act establishes property, disciplinary, administrative and criminal liability for violations of environmental protection legislation. Thus, the Criminal Code of the Russian Federation contains Chapter 26 "Environmental crimes," the Code of Administrative Offenses of the Russian Federation has the Chapter 8 "Administrative offenses in the field of environmental protection and management". Without a detailed analysis in this article we draw attention to a rather wide list of offenses and crimes in the field of environmental well-being and security. However, in our opinion, for the legitimate use of the environment, it is not enough not to commit offenses and crimes, it is necessary to use natural resources rationally, efficiently, carry out measures to fill them and restore them. It is therefore important to establish at the legislative level a concept of environmental management that meets the requirements of the rule of law and includes provisions that promote the conservation and protection of resources used for production in the agricultural industry.

In science of the ecological right there are the following types of environmental management: rational, steady, sustainable, degradatsionny. In view of the lack of adequate legal regulation in this area there is a problem of distinguishing between the types mentioned above that makes it difficult to apply legislation on the liability of those responsible for environmental offences and crimes, compensation for damage caused by an environmental offence or offense, as well as adequate legal response to activities harmful to the environment. 
Environmental management is a priority goal of reforming the approach to the use of natural resources. Of course, we understand that the problem of rational environmental management is complex and must be solved by consolidating various scientific knowledge from the fields of ecology, agrochemistry, agronomy, agrophysics, zootechny and other sciences, taking into account the modern achievements of technology and technology. However, the possibility of establishing mandatory prescriptions, the support and provision of the State in regulating the relations under consideration have normative prescriptions. That is why it is so important to establish legal definitions that eliminate discrepancies and establish clear legal boundaries for the use of natural resources. We consider successful the definition of environmental management by Luneva E.V., which means the use of nature, leading to an improvement in the qualitative, quantitative characteristics of the ecological system, i.e. increases its ecological capacity, resistance to negative anthropogenic impacts (a kind of evolution of the ecological system), as well as the most economical and careful attitude to non-renewable natural resources.

Returning to the specifics of nature management in agriculture, it should be noted that traditionally the "basis" of agro-industry is land as a natural component of the environment. In accordance with article 77 of the Land Code of the Russian Federation, agricultural lands are recognized as lands located outside the borders of settlements and provided for the needs of agriculture, as well as intended for these purposes. In 2020, agricultural land in Russia amounted to 81.7 million hectares, which represents $22.3 \%$ of the total land composition. This is the second largest after the land of the forest fund. (Figure 1).

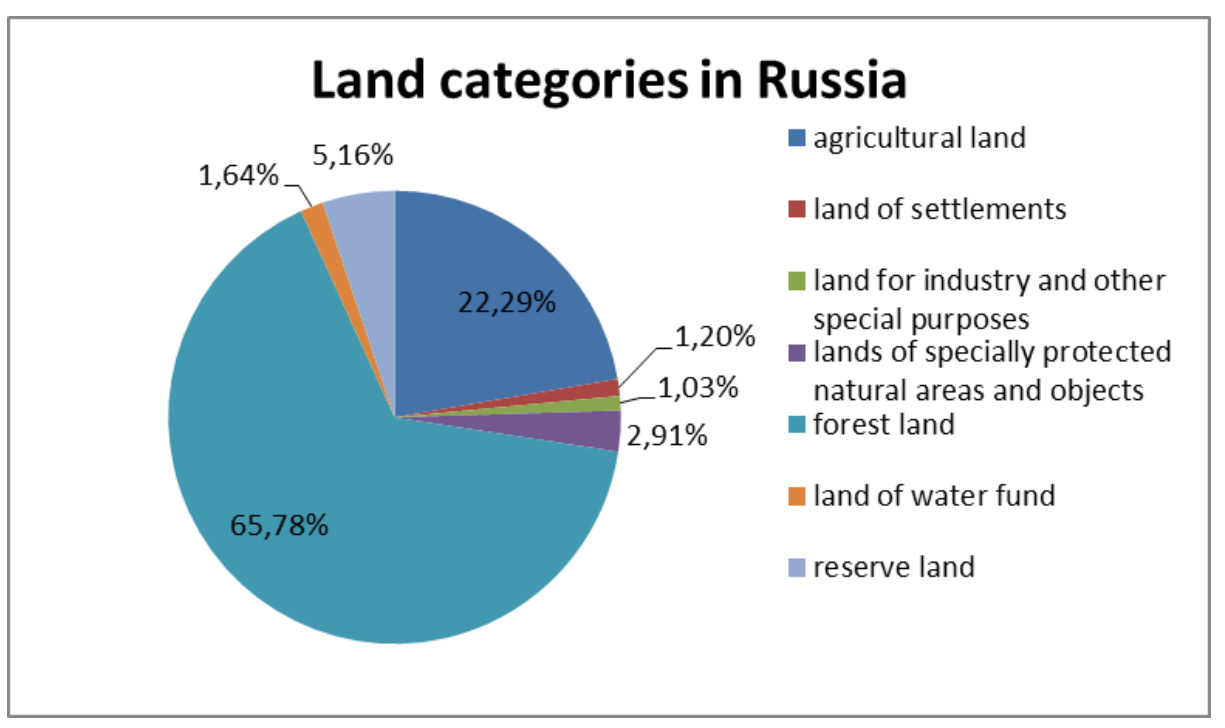

Fig. 1. Land categories in Russia.

The legal regime of agricultural land at the federal level is regulated mainly by the Land Code of the Russian Federation, Federal Law of July 16, 1998 N 101-FL "On State Regulation of the fertility of Agricultural Land," Federal Law of July 24, 2002 N 101-FL "On the Turnover of Agricultural Land." In the production of agricultural products, in addition to land, soil, it affects other natural resources, such as water, vegetation, forests, animals, and atmospheric air. For example, to clear the area, trees and shrubs are cut down to grow crops, grass cover is destroyed, the habitat of insects, animals and birds is changed, water is used for watering. All this demonstrates the need for an integrated approach to environmental regulation. Using a particular natural resource, man invades a certain ecosystem. 
Studying issues of environmental management scientists investigate the use of individual natural resources land, water, etc. Addressing issues of environmental management in agriculture it is necessary to consider rational environmental management comprehensively as part of a special natural-climatic territory created by man in whole or in part which includes several natural components.

Selivanova K.A. proposes to fix the so-called agrarian ecosystems with the object of legal protection. What is meant by artificially created or modified ecosystems that have spatial boundaries where natural and natural-anthropogenic objects interact with each other as a single functional whole, are connected by the exchange of substance, energy and human impact in order to improve agricultural production.

In the absence of a codified act the complexity of the multifaceted environmental legal relations, it seems difficult to determine the specifics of the right to environmental management in agricultural activities. Certain legislative acts differentiate legal regulation of relations depending on the functional purpose of the subject of regulation. For example, modern Russian legislation will define the concept of agricultural land. This definition is contained in the Land Code of the Russian Federation. Agricultural land is defined as land outside human settlements intended for the needs and purposes of agriculture. The legislative act contains chapter XIV which contains rules defining the specifics of the legal status and characteristics of the use of agricultural land.

The Law "On Environmental Protection" contains Art. 42 which establishes requirements in the field of environmental protection in the implementation of activities in the field of agriculture. The legislator established the duties of the entity carrying out agricultural activities to comply with environmental protection requirements, to carry out measures for the conservation and restoration of the natural environment, rational use of natural resources, ensuring environmental safety, preventing negative environmental impact, as well as to carry out standardization in the field of environmental protection. In this list, on the basis of the principle of payment for environmental management, it is also possible to include the obligation to pay fees for the use of natural resources in a timely manner. We can conclude on the basis of sectoral and special legislation that the obligation to compensate for damage caused by a guilty environmental crime or an offense that encroaches on relations in the field of environmental protection and management.

The list of rights of environmental users in the field of agricultural activity is much wider. The rights of environmental management entities are determined by special legislation depending on the specifics of the activities and types of natural resources used. In general, you can distinguish several areas that determine the types of rights of the nature user. Thus, agricultural actors have the right to use natural resources to carry out their activities in ways that are not harmful to the environment; to extract useful properties from resources found within the territories provided to them in accordance with the law or contract; to provide information on the state of the natural environment in accordance with the guarantees enshrined in the Constitution of the Russian Federation.

Problems of environmental management, protection of the natural environment, reproduction of natural resources in agriculture require improved legal regulation in the field of agricultural production. As we have mentioned above these problems are complex in nature, therefore, in the state regulation of the area under consideration, other social and economic measures should be used in addition to legal ones. In this vein, the experience of foreign countries in implementing policies aimed at the ecological, rational use of natural resources in agriculture is of interest [8,9].

Scientists propose the following measures to solve problems of environmental management in the Republic of Kazakhstan. In order to overcome the irresponsible attitude of public officials to the implementation of policies in the studied area, it is proposed to legislate the obligation of the government to annually report on the progress of state national 
programs in the agrarian sphere to the public. For the special protection of farmland, it is proposed to establish legislative restrictions on the rotation of valuable farmland, establishing prohibitions on the transfer of individual agricultural land to private ownership.

In order to ensure public access to information on the state of land resources, it is necessary to establish a rule on the publication of annual reports on the state of the land fund in the official media as an effective mechanism for public control over the activities of government bodies and authorities. Economic incentives for environmental agricultural production should also be developed.

The codification of agrarian legislation will eliminate the isolated and unsystematic nature of the current legislation will provide a comprehensive and systematic approach to the legal regulation of agrarian relations; address contradictions, gaps and different interpretations; Establish a right-wing mechanism for wildlife management and environmental conservation in the agricultural sector; harmonize legislation in accordance with international norms and requirements in conditions of Kazakhstan's accession to the WTO. [10]

In Poland a special attention is paid to the protection of agricultural land and forests. Agricultural land and forests received comprehensive protection under the provisions of the Act of 26 October 1977 on the protection of agricultural land, forests and land reclamation. This legal act laid the foundations for the protection of agricultural land and forests in the following decades. Legislation on the protection of agricultural land and forests limits the area of agricultural land and forest land that can be converted into other categories of land. These laws also encourage the conversion of agricultural land that is least suitable for agricultural production. Responsibility for developing sustainable land management policies rests with the authorities at all levels of the national administration, but mainly with the local authorities [11].

An interesting study was conducted on farmers' awareness of various aspects of environmental protection in Saudi Arabia. The level of awareness among farmers of agroenvironmental legislation aimed at protecting the environment has been studied by interviewing Saudi farmers on various aspects of environmental legislation. During the survey, knowledge of the law, awareness of responsibility for violations of environmental legislation and causing harm to protected objects were checked. The study showed a low level of awareness of sanctions of environmental offenses. In addition, a low level of knowledge of pesticide legislation among farmers has been identified. Farmers have demonstrated a higher level of knowledge in the area of environmental legislation. In terms of public policy development, it is important to raise farmers' awareness of existing agroenvironmental legislation, as this can serve as a basis for developing incentives for compliance with legal regulations [12].

The discussed examples demonstrate various approaches aimed at improving government regulation in the field of reducing the harmful impact of agricultural activities on the state of the natural environment $[13,14,15]$. The development of agrarian law in the Russian Federation with its subsequent codification is seen as positive in this direction. The Agrarian code would help to eliminate the fragmentation, inconsistency and gaps in Russian legislation in the field of regulating relations in the field of agricultural production including in the field of environmental law. We support the idea of strengthening the responsibility of public officials for the implementation of policies on greening agricultural production. Positive is the idea of improving the environmental and legal literacy of agricultural actors.

\section{Conclusions}

In today's world environmental and natural resource management issues have received considerable attention. In this regard the role of reforming approaches to environmental 
management in agriculture is important. Agricultural environmental management has its own specificity due to mutually exclusive factors: on the one hand, agro-industry is carried out through the use of natural resources and harmful environmental impact (in case of unfair use) on the other. Based on the study we concluded that there is a need to improve Russian legislation in order to achieve the goals of environmental management, environmental protection, reproduction and restoration of natural resources. The prospect of the adoption of the Agrarian Code of the Russian Federation is positive which unites issues of legal regulation of various areas of agricultural activity.

\section{References}

1. N. Alexandratos, J. Bruinsma, World agriculture towards 2030/2050: the 2012 revision, 12-03 (2012) - ageconsearch.umn.edu

2. D. Tilman, C. Balzer, J. Hill, and B. L. Befort, Proceedings of the National Academy of Sciences of the United States of America, 108 (50), 20260-20264 (2011)

3. C. Paula, A.-K. Techena, J. Scott, et al., Journal of Cleaner Production, 227, 1054-1067 (2019) doi: 10.1016/j.jclepro.2019.04.115

4. V. Mauerhofer, Ecosystem Services, 29(B), 185-189 (2018)

5. B.L.Avelhan, D.Zylbersztajn, RAUSP Management Journal, 53 (2), 178-189 (2018)

6. J.Noria, J.N.Lescano, P.Illoldi-Rangel, et al., Biological Conservation, 159, 507-513 (2013)

7. R.Mannersab, J.Ettenc, Global Environmental Change, 53, 182-194 (2018)

8. F. Ramóna, C. Lullb, Environmental Pollution, 250, 883-891(2019)

9. I. Roitmana, L. Cardoso, G. Vieiraa, et al., Land Use Policy, 76, 95-102 (2018)

10. L. K. Yerkinbayeva, A. E. Bekturganov, Procedia - Social and Behavioral Sciences, 81, 514-519 (2013)

11. K.Kurowska, H. Kryszk, P. Leń, Land Use Policy, 95, 104614 (2020) doi: 10.1016/j.landusepol.2020.104614

12. B. A. Alotaibia, H. S. Kassemab, A. AL-Zaidia, et al., Land Use Policy, 99, 104902 (2020)

13. E. Balashov, I. Vladimirov, R. Gizzatullinb, et al., Journal of the Saudi Society of Agricultural Sciences. Available online (2020)

14. H. Schoukens, Land Use Policy, 67, 178-189 (2017)

15. C. Hamilton, A. Macintosh, N. Patrizi, et al., Encyclopedia of Ecology (Second Edition), 4, 319-326 (2019) 